\title{
Forestillede forskelle \\ - En barriere for gensidig integration og fællesskaber mellem unge med forskellig etnisk baggrund
}

I denne artikel analyseres oplevelsen af fællesskab blandt unge med forskellig etnisk baggrund på en 10.-klassekole i Albertslund. På trods af en fælles opvækst i de kommunale institutioner, hvor der er en ligelig fordeling af de etniske grupper, er de unge tydeligt socialt opdelt. Således går unge med dansk baggrund sammen, ligesom unge med anden etnisk baggrund end dansk gør det. De unge udviser stor tolerance for hinanden, men også en vis ligegyldighed og distance. Dette kan undre, når man tager de unges i øvrigt mange ligheder og fælles interesser i betragtning. Der argumenteres for, at en række forestillede forskelle blænder de unge for disse ligheder, og at de forestillede forskelle hindrer oplevelsen af fællesskab mellem de unge med dansk og anden etnisk baggrund. Forestillede forskelle hæmmer således den gensidige sociale integration. 
$\mathrm{I}$ ntegration af etniske minoriteter i Danmark er et tilbagevendende tema i den offentlige debat. Undersøgelser dokumenterer med jævne mellemrum en lav grad af interaktion mellem personer med henholdsvis dansk og anden etnisk baggrund. Mange steder i Danmark vokser unge med dansk og anden etnisk baggrund imidlertid op side om side, idet de blandt andet går i børnehave, skole og på fritidshjem sammen. Blandt disse unge burde man kunne forvente en langt højere grad af interaktion og kontakt på tværs af den i samfundet udbredte, dikotomiske opdeling mellem "danskere" og "indvandrere". De unge kan dermed give et andet perspektiv på integrationsdebatten ved at symbolisere en ny generation i Danmark, hvor interaktion på tværs af kulturer og etnisk baggrund gennem hele deres opvækst har været en naturlig del af hverdagen ${ }^{1}$.

Denne artikel baserer sig på en undersøgelse af unge på Albertslund Kommunes 10.-klasseskole, Det 10. Element ${ }^{2}$. I Albertslund er mere end 23 procent af kommunens indbyggere indvandrere, flygtninge eller efterkommere af disse, hvilket placerer Albertslund som den kommune i Danmark, der har tredje flest indbyggere med en anden etnisk baggrund end dansk (Danmarks Statistik 2006). Albertslund er geografisk opdelt med velhavende villakvarterer i nord og et socialt belastet boligområde i syd, hvor der bor mange familier med anden etnisk baggrund. For at udligne denne opdeling har Albertslund -i forhold til landets øvrige kommuner - en meget progressiv integrationspolitik. På skoleområdet kommer dette til udtryk ved, at man i mere end 10 år har fordelt elever ligeligt på kommunens skoler på baggrund af sprogtest, og dermed ofte ud fra etnisk baggrund. Alle kommunens skoler har derfor mere eller mindre samme andel af elever med en etnisk minoritetsbaggrund, og på Det 10. Element har en tredjedel af eleverne en anden etnisk baggrund end dansk. Ved at vælge kommunens 10.klasseskole som en illustrativ case blev det muligt at få et billede af den gensidige integration blandt unge med forskellig etnisk baggrunde der har haft en fælles hverdag gennem hele deres skolegang.

I denne artikel analyseres de fællesskaber, som unge med forskellig etnisk baggrund oplever, og herunder også hvad der hæmmer følelsen af fællesskab på tværs af dansk og anden etnisk baggrund. I artiklen vil vi præsentere mulige forklaringer på, hvorfor de unges oplevelse af fællesskab oftest er begrænset til enten at gælde unge med dansk eller anden etnisk baggrund. Undersøgelsens empiriske grundlag består af deltagerobservationer på Det 10. Element, interview med 22 unge både individuelt og i mindre grupper samt interview med skoleinspektøren og udvalgte lærere.

\section{En velfungerende omgangsform}

Det 10. Element er generelt præget af en god stemning og positiv ånd, hvilket blandt andet kommer til udtryk gennem fravær af konflikter og en god omgangstone blandt de unge. Sideløbende med den positive omgangsform er der en udtalt opdeling af de unge mellem dem, der har en dansk baggrund på den ene side og dem med anden etnisk baggrund på den anden side. Dette kommer til udtryk 


\begin{tabular}{|l|l|l|}
\hline & Sabine Klinker & Marie Hvoslef \\
& Stud.scient.soc & Rasmussen \\
& ved Sociologisk & Stud.scient.soc \\
Institut, Københavns & Universitet. & ved Sociologisk \\
& E-mail: \\
sabine.klinker@gmail. & Institut, Københavns \\
& Universitet. \\
& & E-mail: \\
& marie@hvoslef.dk \\
\hline
\end{tabular}

ved en begrænset interaktion mellem disse grupperinger. De unge beskriver disse opdelinger og deres oplevelser af dem i interviewene. Lea, der har dansk baggrund, udtrykker for eksempel opdelingerne således: "Danskerne og indvandrerne holder sig hver til sit, ikke fordi der er problemer, men vi er bare ikke så meget sammen. Jeg ved ikke hvorfor, det virker bare mest naturligt".

Mens de unge med dansk baggrund primært er venner med dem, der også har dansk baggrund, danner de unge med anden etnisk baggrund derimod mange venskaber på tværs af etnisk baggrund - men sjældent med unge med dansk baggrund. Selma, der har marokkansk baggrund, fortæller: "Det er ligesom, at vi er vant til hinanden, indvandrere ikk, og så tror jeg også mere, at de er vant til hinanden. De har det jo også bedre med at være venner med danskere end med indvandrere". De unge med anden etnisk baggrund mener, at de bedre forstår hinanden, fordi de har en indvandrerbaggrund tilfælles, også selvom deres nationale baggrund ikke er den samme ${ }^{3}$.

\section{Lige børn leger bedst?}

Hverdagen og grupperingerne på Det 10. Element kan beskrives ud fra Peter Berger og Thomas Luckmanns teorier om typeskemaer og virkelighedsforståelse. Typeskemaer er det nødvendige grundlag, ud fra hvilket individet typificerer begivenheder, oplevelser og personer (Berger \& Luckmann 1979:58). Den enkeltes typeskema er i høj grad præget af familien, man vokser op i, men typeskemaet er dog under konstant forandring livet igennem. Dette skyldes, at typeskemaet formes af den virkelighedsforståelse, det enkelte individ udvikler. I barndommen er internaliseringen af forældrenes virkelighed i den primære socialisering nærmest uundgåelig, idet forældrene, i henhold til George Herbert Mead, indtager rollen som den signifikante anden for barnet i dets udvikling af rolleovertagelse (Mead 1934). Således er den primære socialisering af eksempelvis direktør- eller arbejderbørn meget forskellig, hvilket medfører, at disse børns virkelighedsopfattelser adskiller sig fra hinanden. Den virkelighed, der internaliseres under den primære socialisering, er svær at disintegrere, hvorimod virkeligheder, der er internaliseret gennem sekundær socialisering er langt mere skrøbelige og derfor lettere at destruere eller tilsidesætte (Berger \& Luckmann 1979:162).

På trods af mindre variationer, træder en lang række ligheder frem i de vilkår, 
som de unge med dansk baggrund er vokset op under, når de sammenlignes med de opvækstvilkår unge med anden etnisk baggrund har haft. De kommer fra familier med danske traditioner og værdier, dansk som modersmål og hvor begge forældre er i arbejde og typisk har taget en mellemlang uddannelse. Tilsvarende er der nogle fællestræk i de opvækstvilkår, som de unge med anden etnisk baggrund har haft. Deres forældre er indvandret til Danmark og er ufaglærte eller har en kortere uddannelse fra oprindelseslandet, der ikke har givet dem job i Danmark. På trods af etniske og kulturelle forskelle mellem de unge med anden etnisk baggrund end dansk, har de generelt tilfælles, at de er muslimer, opfatter sig selv som indvandrere i Danmark og kommer fra en familie, som har en relativt lav socioøkonomisk position i det danske samfund.

I Berger og Luckmanns optik har de unge i deres primære socialisering internaliseret forskellige virkeligheder, der i dag ligger dybt i deres bevidsthed og er afgørende for deres forståelse, væremåde og handlinger, selv om de i den sekundære socialisering - gennem for eksempel skolesystemet - også har internaliseret andre virkeligheder. Det er lettere for personer med lignende typeskemaer at forstå hinanden, fordi de er enige om, hvorledes omgivelserne typificeres, og de undgår derfor tilbagevendende forhandlingsprocesser med hinanden. Dermed giver Berger og Luckmanns teori et interessant perspektiv på, hvorfor de unge med henholdsvis dansk baggrund og anden etnisk baggrund grupperer sig, som det er tilfældet på Det 10. Element, det vil sige i overensstemmelse med typeskemaer og virkelighedsforståelser.

En lignende forståelse af de unges grupperinger finder man hos Bourdieu, der hævder, at agenter i det sociale rum, hvis positioner og habitus ligner hinanden, har større sandsynlighed for at mødes og komme overens, end agenter med positioner langt fra hinanden (Bourdieu 2003:27). I henhold til Bourdieu vil de unge med dansk baggrund være placeret nærmere hinanden i det sociale rum og have et større sammenfald i habitus, ligesom de unge med anden etnisk baggrund vil have større sammenfald med andre med lignende baggrund.

Dette kan give en ramme til at forklare, hvorfor de unge føler, at det er lettere og mere naturligt at være sammen med andre, der - i større eller mindre grad opleves at have samme baggrund som dem selv. Berger og Luckmanns teori er imidlertid mere velegnet til at forstå de unges grupperinger end Bourdieus, fordi typeskemaer og virkelighedsforståelser har en mere foranderlig karakter end habitus-begrebet, som er relativt statisk. Bourdieus forståelse af aktører giver et for deterministisk perspektiv på de unge, fordi de også besidder en tilpasningsevne, der gør dem i stand til at indgå i meget forskellige sociale sammenhænge. Et eksempel på denne tilpasningsevne er den velfungerende hverdag på Det 10. Element, som Berger og Luckmanns teori om sekundær socialisering kan bidrage til at forstå. Ifølge Berger og Luckmann er virkelighed socialt konstrueret, og der eksisterer flere virkeligheder, hvoraf én adskiller sig som den overordnede: hverdagens virkelighed. Den danner en fælles social realitet og commonsense, det vil sige en intersubjektiv virkelighed, der skabes og deles socialt (Berger 
\& Luckmann 1979:35ff). Gennem samværet på Det 10. Element har de unge skabt en sådan fælles hverdagens virkelighed, forstået som en fælles forståelseshorisont og referenceramme, som deres omgangsform bygger på. Den fælles forståelseshorisont, der er skabt på skolen, tager udgangspunkt i gensidig tolerance, men også i opdelinger, der accepteres som "naturlige" , hvilket også bevirker, at man ikke generer hinanden på tværs af opdelingerne.

\section{Inklusion i forestillede fællesskaber}

Det nationale tilhørsforhold opfattes som medfødt og naturligt og spiller en afgørende rolle for de unge, idet de føler et stærkt fællesskab og tilhørsforhold med andre, der har samme nationale baggrund som dem selv. Benedict Anderson beskriver det nationale som et forestillet fællesskab, der afgrænser sig fra andre nationer, og er karakteriseret ved at se bort fra aktuelle uligheder internt i nationen (Anderson 1991:7). Særligt for de unge med en anden etnisk baggrund end dansk er det følelsesladet at fremhæve det nationale tilhørsforhold til en anden nation end Danmark, selvom de set udefra har et stærkt tilhørsforhold til Danmark, hvor de fleste er født, opvokset og har deres hverdag. Dette illustreres i nedenstående fokusgruppediskussion mellem seks unge med kurdisk baggrund:

Erbil: Indvandrere her i Danmark, det er os

Taner: Du er ikke indvandrer, du er dansker ligesom de andre

Erbil: Nej (Siger noget mere på kurdisk)

Interviewer: Du vil ikke kaldes dansker, Erbil?

Figen: Fordi det er han ikke/

Erbil: Fordi jeg betragter mig som en kurder

Figen: Hvorfor kan man sige, at bare fordi man er født/

Sami: Det er jo ikke ensbetydende med, at bare fordi man er født i Glostrup er man dansker. Altså, fordi en kylling bliver født i en kostald, så bliver den jo ikke en ko.

Blandt de unge med anden etnisk baggrund end dansk er det generelt ikke positivt at blive opfattet som dansker, fordi de føler tilhørsforhold til et andet nationalt fællesskab, hvilket ikke nødvendigvis ændres af, at de er født og opvokset i Danmark.

Hos de unge med dansk baggrund omfatter det nationale fællesskab alle, der har dansk baggrund, på tværs af alder, køn og samfundsklasse, mens de konsekvent fremhæver, at unge med anden etnisk baggrund er "indvandrere", "perkere" eller tilhører et andet nationalt fællesskab end det danske.

Det nationale fællesskab er i denne forstand forestillet frem for reelt, idet man 
ikke personligt kender alle dem, man føler dette fællesskab med, ligesom fællesskabet udstrækker sig på tværs af tid- og rumdimensioner. De unge med anden etnisk baggrund end dansk føler - på tværs af fysisk afstand, og uafhængigt af hvor de er født og opvokset - et nationalt fællesskab med den nation, hvor deres forældre kommer fra ${ }^{4}$. Denne tilhørsfølelse giver dem et fællesskab med andre unge, hvis forældre har oprindelse i det pågældende land. Det imaginære element i fællesskabet mellem de unge med anden etnisk baggrund end dansk kommer til udtryk ved, at disse unge følelsesmæssigt definerer sig som værende en del af et nationalt fællesskab, hvor forskelle, der adskiller fællesskabet, såsom at de er bosat i forskellige lande, har forskellige livsbetingelser, afvigende livsstile og kulturpåvirkninger, tillægges mindre betydning end det, der forener fællesskabet, nemlig den fælles nationale baggrund. De unges nationale forestillede fællesskaber overskrider således både fysiske grænser og sociale forskelle, men udspiller sig også lokalt på Det 10. Element, hvor de unge, der opfatter sig selv som en del af de samme nationale forestillede fællesskaber, føler en særlig samhørighed og ansvarsfølelse i forhold til hinanden.

Det fællesskab, som de unge med anden etnisk baggrund finder i kraft af identiteten som "indvandrere" eller "perkere" i Danmark, kan betragtes som et forestillet fællesskab med samme karaktertræk som nationale forestillede fællesskaber dog uden at være rettet mod en nation. Gennem islam skaber de unge en fælles kulturel oplevelse, og følelsen af at være en "gruppe af samme slags" forstærkes af den fælles indvandrerbaggrund. På samme måde som i det forestillede nationale fællesskab overskygges forskellighederne af det, der forener dem, nemlig at være ikke-dansk. Det forestillede fællesskab, "indvandrere", overskrider således store kulturelle forskelle og omfatter personer, man ikke kender personligt. Endvidere fremhæves det forestillede fællesskab som "indvandrere" situationelt, ligesom det eksisterer parallelt med det individuelt forestillede nationale fællesskab.

\section{Forestillede forskelle}

Skal man forstå de unges oplevelser af fællesskab og de opdelinger, de medfører, er det bemærkelsesværdigt, at de fleste unge, uanset etnisk baggrund, foretager sig de samme ting med deres venner, og at deres fællesskaber bygger på flere af de samme aktiviteter og værdier. For eksempel er fyre, tøj og musik de mest omdiskuterede emner blandt pigerne, men de snakker sjældent med hinanden om det på tværs af opdelingen. Interesserne forener altså ikke pigerne, der i stedet fokuserer på den afgørende forskel imellem dem; nemlig, at piger med dansk baggrund har kærester og er sammen med fyre, hvilket piger med anden etnisk baggrund ikke er. Pigerne har imidlertid mange ligheder. De er modebevidste, bruger meget make-up og ligner udefra piger, der kunne være veninder. Man kan derfor argumentere for, at der er et potentielt stilbaseret interessefællesskab mellem pigerne - selvom pigerne ikke selv oplever dette fællesskab. Blandt drengene viser det sig, at de fleste, på tværs af opdelingen, tager til fester og har kæ- 
rester, ligesom de interesserer sig for computerspil, fodbold og basketball, og at det er disse ting, de fremhæver i forhold til deres følelse af fællesskab med andre. Det viser sig imidlertid, at drengene med dansk baggrund kun føler fællesskab omkring disse ting sammen med andre unge med dansk baggrund, ligesom de unge fyre med anden etnisk baggrund kun føler fællesskab omkring disse interesser med andre med en anden etnisk baggrund. Det tyder således på, at etnicitet spiller en større rolle end interesser i forhold til oplevelsen af fællesskab. Samtidig indikerer det, at der er en form for uoverensstemmelse mellem på den ene side de faktiske fællesskaber, såsom at gå til fest eller spille fodbold sammen, og på den anden side de fællesskaber, som de unge selv oplever.

At de unge ikke føler fællesskab på trods af sammenfald i interesser, kan til dels forklares ud fra det, vi-med inspiration fra Andersons begreb forestillede fællesskaber - vælger at betragte som forestillede forskelle. Begrebet forestillede forskelle dækker over, at de unge fremhæver enkelte forskelle imellem dem hovedsageligt mellem det at være "indvandrer" og muslim over for at være "dansker" og ikke-muslim - og derefter generaliserer denne forskel. Dette gør sig både gældende blandt drengene og pigerne, der, med udgangspunkt i særligt den religiøse forskel, forestiller sig yderligere forskelle om hinanden, som "objektivt" set ikke eksisterer. Således forestiller de unge med henholdsvis dansk og anden etnisk baggrund sig gensidigt, at De Andre snakker om helt andre emner og laver helt andre aktiviteter med deres venner end de selv gør med deres vennerhvilket, som beskrevet ovenfor, imidlertid ikke er tilfældet.

Sådanne forestillede forskelle fungerer som en barriere for, at de unge oplever fællesskab på tværs af religiøs og henholdsvis dansk og anden etnisk baggrund. Idéen om forestillede forskelle skal ikke forstås som en afvisning af, at der eksisterer reelle forskelle mellem de unge med henholdsvis dansk og anden etnisk baggrund. Det gør der naturligvis, og i teenagealderen er det en væsentlig forskel, hvorvidt man for eksempel må have en kæreste eller ej. Forskellen ændrer dog ikke på de mange ligheder og interessesammenfald, der samtidig gør sig gældende. Derfor hjælper forestillede forskelle som begreb til at forklare, hvorfor de unge hverken ser eller værdsætter de mange ligheder, der også er mellem dem, men snarere er fanget i en forståelse af hinanden, der er fokuseret på forskelle. De forestillede forskelle giver de unge en oplevelse af ikke at have noget til fælles på tværs af opdelingen mellem unge med dansk og anden etnisk baggrund. Dermed blænder de forestillede forskelle for de ligheder og potentielle fællesskaber, som de unge kunne være en del af.

Det skal dog nævnes, at enkelte unge oplever at have fælles interesser og venskaber på tværs af opdelingen mellem henholdsvis unge med dansk og anden etnisk baggrund. Selvom denne form for "kulturel brobygning" kun praktiseres blandt få af de unge, viser den, at andre fællesskaber er mulige, og at de forestillede forskelle kan overkommes ${ }^{5}$.

Der kan drages en parallel mellem forestillede forskelle og begrebet forskellighedsracisme, som er karakteriseret ved, at man påpeger forskelle hos De An- 
dre, og at eventuelle ligheder blot fører til konstruktion af flere forskelle (Røgilds 2002:107, Azar 2001:59). Forskellighedsracismen tager imidlertid udgangspunkt i et ulige magtforhold, hvor majoriteten påpeger det, der er anderledes ved minoriteten, hvorved der konstrueres forskelle, der ekskluderer minoriteten fra det nationale fællesskab. Derimod skal forestillede forskelle forstås som gensidige mellem grupper, hvor magtforhold ikke bestemmes ud fra relationen mellem majoritet og minoritet. Den offerrolle som etniske minoriteter tillægges i henhold til forskellighedsracismen gør sig ikke gældende på Det 10. Element, hvor de unge uanset etnisk baggrund selv er med til at skabe deres position i det sociale hierarki på skolen gennem deres tøjstil, omgangskreds og adfærd.

\section{National kapital og perker kapital}

Det kan vække undren, at nogle af de unge med anden etnisk baggrund - selvom de er født og opvokset i Danmark, taler flydende dansk og indgår i en dansk hverdag - ikke betragter sig selv som danske, og heller ikke bliver betragtet som danske af deres skolekammerater med dansk baggrund.

Kultursociolog Iben Jensen arbejder i sine studier af unges interkulturelle kompetencer med begrebet national kapital. Inspireret af Bourdieus kapitalformer har Jensen udviklet dette begreb, der er knyttet til nationalkultur på den måde, at hvis man er født i Danmark af forældre, der begge tilhører nationalkulturen, så besidder man national kapital (Jensen 2001:144ff). Den nationale kapital er dels udtryk for de holdninger og den adfærd, der er anerkendt af medlemmerne af det nationale fællesskab, og dels er national kapital udtryk for et udefinerbart "noget", som kun personer med den pågældende nationale baggrund besidder. De unge med anden etnisk baggrund mestrer, i større eller mindre grad, de holdninger og den adfærd, som er anerkendt i det danske samfund, men de er - ifølge Jensens definition - ikke i besiddelse af dansk national kapital, fordi deres forældre er indvandret til Danmark. Den danske nationale kapital bruges eksempelvis af de unge med dansk baggrund i undervisningssituationer og omgangen med lærerne, hvor der hersker en vis indforståethed, som de unge med anden etnisk baggrund ikke er en del af. Eksempler på dette er gamle ordsprog og talemåder, referencer til film som Far til Fire og Olsen-banden, danske børnebøger samt påske- og juletraditioner.

En anden kapitalform kan identificeres på Det 10. Element, og denne kapital anvendes og konstrueres som et modstykke til dansk national kapital. Denne kapitalform tager udgangspunkt $i$ at have sine kulturelle og religiøse rødder et andet sted end i det danske samfund. Vi benævner denne perker kapital, idet "perker" er den betegnelse, som de fleste unge med anden etnisk baggrund bruger om sig selv og det fællesskab, som de identificerer sig med. Ordet "perker" er i det danske sprog negativt ladet og bruges nedsættende, men de unge med anden etnisk baggrund har taget denne betegnelse til sig og har vendt negationen til noget, der i deres øjne er positivt, og som de kan bygge deres identitet op omkring ${ }^{6}$. De unge med anden etnisk baggrund afgrænser perkerfællesskabet 
meget skarpt, idet man for at være perker skal have indvandrer- eller flygtningebaggrund og være muslim. Et af kendetegnene for perker kapital er den særlige sprogform som de unge, der identificerer sig med perkerfællesskabet, situationelt gør brug af .

De unge med anden etnisk baggrund, der kalder sig selv perkere, mener, at unge med dansk baggrund højst kan få status som "perker-wanna-be" eller "plastik-perker"; det vil sige, at de aldrig kan blive fuldgyldige medlemmer af fællesskabet ${ }^{8}$. De unge med anden etnisk baggrund er bevidste om deres særlige sprogbrug, hvilket forstærker dets funktion som en gruppemarkør. Følgende uddrag fra et fokusgruppeinterview med unge med henholdsvis iransk, albansk og libanesisk baggrund eksemplificerer dette:

Ibrahim: Indvandrere kan heller ikke lide, når danskere prøver at spille indvandrere, altså at spille perkere. Når danskere siger "wallah", lyder det åndssvagt

Ahmed: De kan ikke finde ud af at sige det rigtigt, de kan ikke lægge tryk på ordene

Ibrahim: De siger "wallah" [efterligner dansk accent: "valla"]

Ahmed: Det er fordi indvandrere, de bruger det der sprog

Samira: Det er vores eget sprog

De unge med anden etnisk baggrund vogter således over deres fællesskab gennem en striks eksklusionsmekanisme. Individuel forhandling er dog en mulighed, hvor unge med dansk baggrund kan tilegne sig "perker-lignende" kvalifikationer, eksempelvis gennem en særlig sprogbrug eller adfærd. Perker-kapitalformen er respekteret på Det 10. Element, hvilket er med til at understrege, at de unge med anden etnisk baggrund ikke skal opfattes som placerede i en offerrolle. National kapital og perker kapital fungerer som gensidige eksklusionsmekanismer i forhold til de respektive fællesskaber. Man kan argumentere for, at kapitalformerne på den måde er med til at dyrke og reproducere de forestillede forskelle blandt de unge, hvilket samtidig medvirker til at opretholde de unges oplevelse af fællesskab.

\section{"Os danskere" - "Os indvandrere"}

Os-Dem distinktionen er en klassisk sociologisk differentieringsproblematik, hvorigennem grupper føler fællesskab ved at skelne Os fra Dem. Zygmunt Bauman beskriver, hvordan fællesskabet er bedst sikret, hvis den enkelte føler ikke selv at have valgt det, eller gjort noget for at frembringe det, eftersom et sådant fællesskab dermed tænkes som en naturlig enhed. Denne naturlighed har dog snarere karakter af at være et postulat - et ønske om enhed - end en realitet. Herudover er en del af det, der konstituerer Os, at der er nogen-Dem-der ikke 
er en del af dette. Alle mennesker har, ifølge Bauman, "need for belonging" i form af et behov for ikke kun at identificere sig som individuelle mennesker, men også som medlemmer af større enheder, gennem hvilke man kan identificere sig kollektivt (Bauman 1998:275).

Der kan være mange årsager til, at Os-Dem dikotomien mellem henholdsvis "indvandrere" og "danskere" er den mest fremtrædende i empirien. En af årsagerne til, at de unge er blevet inspireret til at tale i denne dikotomi, kan tænkes at være, at den er fremtrædende i samfundsdebatten. Samtidig er "Os danskere" såvel som "Os indvandrere" fællesskaber, der opleves som naturlige for de unge, og dermed en oplagt mulighed for at identificere sig kollektivt. Den dikotomiske opdeling mellem unge med henholdsvis dansk og anden etnisk baggrund i Os og Dem hæmmer følelsen af fællesskab på tværs blandt de unge og dermed også den gensidige integration, som tilstræbes gennem kommunens integrationspolitik.

"Os danskere" er blandt de unge med dansk baggrund i høj grad bygget op omkring, at der er en gruppe, der er anderledes og fremmede, og derfor ikke en del af dette Os. Dette udtrykker for eksempel Tor: “Vi forstår hinanden bedre og vores kultur og sådan. Men indvandrerne er jo anderledes, fordi de kommer fra et andet sted". Tilsvarende denne konstruktion af "Os danskere", opfatter de unge med anden etnisk baggrund "Os indvandrere", som at være noget andet end dansk, som beskrevet ovenfor. De forskellige oplevelser af Os på Det 10. Element tager således gensidigt udgangspunkt i en konstruktion af de unge med anden etnisk baggrund som en form for "fremmede" $\mathrm{i}$ forhold til det danske.

Georg Simmel beskriver med tankefiguren den Fremmede en person, der kommer i dag og bliver i morgen, og på én og samme tid er både nær og fjern (Simmel 1950:402ff). Bauman videreudvikler begrebet om den Fremmede og hævder, at den Fremmede aldrig kan blive en del af "de indfødte", uanset hvad denne gør for at blive opfattet som en del af de indfødtes gruppe. Hos Bauman er det ikke muligt for de Fremmede at frigøre sig fra denne kategori. Jo mere aktivt de prøver, desto tydeligere bliver det, at de er Fremmede (Bauman 1998:94).

At de unge med anden etnisk baggrund på Det 10. Element bliver opfattet, og til dels også opfatter sig selv, som "fremmede", lader sig dog ikke forklare af Simmel og Baumans teorier om den Fremmede. De unge med anden etnisk baggrund stræber nemlig ikke efter at være "danskere" eller indfødte, som Baumans læsning af den Fremmede antyder. Dertil kommer, at de unge med anden etnisk baggrund er født og opvokset i det danske samfund, hvorfor det også forekommer en anelse paradoksalt at betragte dem som Fremmede i Simmels og Baumans forstand. Den form for "fremmede", som de unge med anden etnisk baggrund end dansk udgør, er derimod til dels udtryk for en tilvalgt identitet, hvorfor Baumans forståelse af den Fremmede som en mere eller mindre uforanderlig karakter, i dette lys synes for deterministisk i forhold til de unge. 


\section{Stereotypiske forestillinger \\ - En forenkling af omgivelserne}

De opdelinger i Os og Dem, der er diskuteret ovenfor, er ofte knyttet til stereotypiske forestillinger om Den Anden. Stereotypiske forestillinger er et mere overordnet og bredere begreb end forestillede forskelle. Mens stereotypiske forestillinger er nogle man oftest har om grupper af personer, som man har et begrænset personligt kendskab til, eksisterer forestillede forskelle derimod mellem personer, der omgås hinanden til hverdag, og som har ligheder og praktiske eller potentielle fællesskaber, de ikke oplever, fordi de opfatter hinanden ud fra en forståelse centreret om forskelle.

Ifølge socialpsykologen David Schneider er stereotypiske forestillinger særlige egenskaber, der opfattes som nogle der tilhører bestemte kategorier af mennesker. Overordnet set har stereotypiske forestillinger to funktioner, henholdsvis en kognitiv og en social funktion. Den kognitive funktion er at simplificere og ordne den sociale verden, det vil sige at vi kategoriserer vores omgivelser for at skabe meningsfulde opdelinger. Den sociale funktion er at dække en gruppes behov for at forklare relationer mellem forskellige grupper såvel som gruppens egen placering i disse relationer. Stereotypiske forestillinger skabes således processuelt som en kamp om mening mellem individer og grupper (Schneider 2004:364f). Gennem differentiering mellem forskellige grupper er det muligt at skabe en positiv selvidentitet, blandt andet ved at tillægge De Andre negative karakteristika. På den måde er social kategorisering og social identitet bundet op på hinanden.

Blandt de unge med anden etnisk baggrund end dansk er en af de hyppigst forekomne stereotypiske forestillinger om personer med dansk baggrund, at de drikker meget, fester meget og ofte har sex med tilfældige partnere. I forlængelse heraf drager disse unge ofte den konklusion, at piger med dansk baggrund er billige. Dette kommer blandt andet til udtryk i følgende citat fra en fokusgruppe blandt unge med kurdisk baggrund:

Figen: Når man tænker på kultur og tager deres kultur og vores kultur, så siger man, at de er billige, for det passer ikke til vores kultur. Men når du tænker på deres kultur, altså danskernes kultur, så er det helt normalt for dem. Altså deres mødre, seriøst, det er totalt klamt, deres mødre, pigernes mødre, de køber beskyttelses-dimser til dem, fordi de fylder 15 år, og så må de gøre alt hvad de vil. De drikker også og sådan noget

Sami: De har samleje/

Erbil: Jeg kender en pige, hvor moren køber de der blade og videobånd til hende.

Interviewer: Hvad er det for nogle blade?

Erbil: Porno blade 
Det ser ud til, at de unge med anden etnisk baggrund har en overdrevet og stereotypificeret forestilling om for eksempel forholdet til sex blandt familier med dansk baggrund. De unge med dansk baggrund forsøger at tilpasse sig en form for politisk korrekthed, når talen falder på fordomme, men de har alligevel fordomme om personer med en anden etnisk baggrund. Eksempelvis forestiller de sig, at personer med anden etnisk oprindelse ofte laver kriminalitet, sort arbejde og nasser på samfundet.

I forhold til hele gruppen af unge kan vi sige, at stereotypiske forestillinger tjener til at lette forståelsen af deres sociale omgivelser, ligesom de fungerer som identitetsgrundlag for de forskellige grupper, der forsøger at fremstille sig selv på en fordelagtig måde ved at placere de andre i negative stereotypiske kategorier'. I praksis har de stereotypiske forestillinger dog en uhensigtsmæssig konsekvens, idet de er med til at forstærke og reproducere de forestillede forskelle, der er mellem de unge. På trods af dette foregår der i mødet mellem de unge imidlertid også en aftypificering af de stereotypiske forestillinger.

\section{"Maja er ikke som de andre danskere" - Om aftypificering}

Stereotypiske forestillinger kan også belyses ud fra Berger og Luckmanns forståelse af typificering, idet stereotypiske forestillinger kan betragtes som en bestemt form for typificering. Når individer møder hinanden, har de ud fra typeskemaerne allerede en forestilling om Den Anden og placerer vedkommende som tilhørende en bestemt type. Mødet ansigt-til-ansigt mellem individer rummer imidlertid et potentiale for at udfordre og nuancere hinandens typeskemaer, idet de gensidigt kan konfrontere hinanden med handlinger, attituder og ekspressive reaktioner, der er i modstrid med den oprindelige typificering (Berger \& Luckmann 1979:43f).

De unge med dansk baggrund skelner mellem de "indvandrere", som de kender fra skolen, og dem, de ikke kender. På samme måde kommer de unge med anden etnisk baggrund med udtalelser om "danskere" generelt, men når de bliver spurgt, om det gælder de unge med dansk baggrund på skolen, svarer de oftest benægtende. Hacer, en pige med kurdisk baggrund, fortæller eksempelvis, at hun oplever danskere som fordomsfulde og racistiske, men fremhæver, at det ikke gælder danskerne på skolen:

De [danskere på skolen] er meget søde, ellers ville jeg ikke omgås dem. Tag for eksempel Maja, hvis jeg mødte hende et andet sted på gaden, så ville jeg tænke, nej, en dansker (forvrænget stemme). Hvis jeg skulle beskrive en dansker, så skulle det være Maja, men nu kender jeg hende, og hun er meget sød.

I ansigt-til-ansigt mødet foregår der ifølge Berger \& Luckmann en forhandling af typificeringerne, hvor der sker en aftypificering af individet og eventuelt en nu- 
ancering af typificeringen. Individerne har i dette møde gensidigt mulighed for at bryde den anonymiserende typificering og fremstå som unikke (Berger \& Luckmann 1979:46). Gennem de unges daglige ansigt-til-ansigt møder udfordres deres typificeringer, således at de oplever hinandens subjektivitet og dermed bliver nødt til at opgive den anonyme typificering i forhold til den enkelte. Det tyder på, at det primært er en aftypificering af individet, der finder sted i interaktionen mellem de unge - snarere end en overordnet nuancering af typificeringerne. De unge holder således fast i den generelle typificering af en gruppe, som opretholdes sideløbende med, at der sker en aftypificering af enkeltindivider.

At de unge i høj grad fastholder de generelle typificeringer kan ses som udtryk for, at stereotypiske forestillinger er svært foranderlige. Stereotypiske forestillinger har en indbygget mekanisme, der gør det muligt for dem at bestå, selvom de konfronteres med inkongruente eksempler. Det vil sige, at møder man en person, som gennem sin individuelle adfærd adskiller sig fra forestillingen om en gruppes stereotype karakteristika, vil man betragte vedkommende som udtryk for en subtype under stereotypen, det vil sige en undtagelse fra reglen. På den måde behøver man ikke at ændre holdning til en bestemt gruppe, selvom man konfronteres med modsatrettede tendenser (Schneider 2004:404). I forlængelse af dette er det sandsynligt, at de unge placerer deres venner og bekendte på skolen som undtagelser, eller sub-typer, mens de kun i begrænset omfang nuancerer den overordnede stereotypiske forståelse af "indvandrere" eller "danskere" gennem ansigt-til-ansigt møderne. Dette forhold kunne potentielt set ændres, hvis de unge oplevede fællesskab på tværs af den udbredte opdeling, idet de så vil ændre den stereotypiske forestilling frem for at skabe individuelle subtyper.

\section{Tolerance - men ligegyldighed?}

Vi har i analysen argumenteret for, at de unge, når de danner fællesskaber, i høj grad er påvirkede af det, som vi betegner forestillede forskelle. Disse forestillede forskelle er udtryk for generaliseringer af enkelte forskelle mellem de unge typisk mellem det at være muslim og ikke-muslim - der overskygger de mange ligheder, som de unge har på tværs af etnisk og national baggrund. Således er de forestillede forskelle en barriere for fællesskaber på tværs af dansk og anden etnisk baggrund. Som modstykke hertil har vi identificeret flere potentielle og praktiske fællesskaber, der tager udgangspunkt i fælles interesser, men som imidlertid ikke opleves som fællesskaber af de unge. Det tyder således på, at etnicitet spiller en større rolle for fællesskabsdannelsen blandt de unge, end vi havde antaget, mens fællesskaber baseret på interesser spiller en underordnet rolle.

Som følge af Albertslund Kommunes fordelingspolitik har de unge gennem deres opvækst været vant til at indgå i sammenhænge, hvor forskellige etniske baggrunde er repræsenteret. Dette har medført, at de unge har udviklet en høj grad af gensidig tolerance, og den velfungerende hverdag på Det 10. Element 
udspiller sig på denne baggrund. Denne tolerance medfører dog ikke, at de unge med henholdsvis dansk og anden etnisk baggrund udviser interesse for hinanden. Tværtimod omgås de generelt hinanden med en vis ligegyldighed og distance. Man kan argumentere for, at et stærkere fællesskab, der ikke er betinget af etnisk og national baggrund, er ønskværdigt, således at de unge kan gøre op med de forestillede forskelle og stereotypiske forestillinger, og der kan foregå en højere grad af gensidig social integration. Med udgangspunkt i det potentiale, som Det 10. Element udgør som casestudie i en kommune, hvor en fjerdedel af borgerne har anden etnisk baggrund end dansk, hvor fordelingen af etniske minoriteter er lige stor $i$ alle kommunens institutioner og folkeskoler og unge med dansk og anden etnisk baggrund derfor er vant til at omgås hinanden dagligt, fristes man til at stille følgende retoriske spørgsmål: Hvis de unge på Det 10. Element ikke oplever fællesskab på tværs af opdelingen mellem "danskere" og "indvandrere", hvad er så udsigterne til, at der fremover vil blive mere interaktion, og at oplevelsen af fællesskaber mellem personer med dansk og anden etnisk baggrund vil vokse andre steder i det danske samfund?

I forlængelse heraf vil det være interessant at overveje, hvordan det danske Os kan inkludere danskere med en anden etnisk baggrund. Det er muligt, at den eksisterende forståelse af det danske nationale Vi kan udvides ved at fokusere på den fælles nutid og fremtid i Danmark frem for at fokusere på en manglende fælles fortid og oprindelse. Man kan også forestille sig, at der konstrueres et "nyt" Os på baggrund af de ligheder, som der i dag er på tværs af den dikotomiske opdeling mellem "danskere" og "indvandrere". Et inkluderende Os rummer en endnu uindfriet forståelse af hvad det vil sige at være dansk. Det er ikke blot anerkendelsen af De Andre, der efterspørges, men snarere, at anerkendelse må udgå fra alle og til alle - såvel minoritet som majoritet - og uanset etnisk eller national baggrund. Dette perspektiv er beslægtet med den multikulturelle fortælling, men tager dog afstand fra multikulturalismens fokus på grupperettigheder, hvis uhensigtsmæssige konsekvens er, at etniske minoriteter fastholdes i etnisk og kulturel forskellighed, hvormed de placeres i en statisk offerrolle.

En mulighed for at realisere dette nye Os kunne være ved at skabe bedre rum i folkeskolen for at udfolde de interessebaserede praktiske og potentielle fællesskaber på tværs af opdelingerne mellem unge med dansk og anden etnisk baggrund. Oplevelsen af fællesskaber rummer et stort potentiale i forhold til den gensidige sociale integration i Danmark, og behovet for en reformulering af et nyt fælles Os, aktualiseres kraftigt af undersøgelsen af de unges fællesskaber på Det 10. Element. 


\section{Noter}

1. Den danske indvandrer- og etnicitetsforskning er siden 1990'erne blevet tilført nye dimensioner, der anlægger et ressourceorienteret og fremadrettet perspektiv på unge med etnisk minoritetsbaggrund og interaktionen mellem unge med forskellig etnisk og national baggrund i det danske samfund (Se for eksempel Necef 1992 \& 1997, Røgilds 1995 \& 2002 og Mørck 1998).

2. Artiklen bygger på en empirisk undersøgelse foretaget i forbindelse med vores hovedopgave på Sociologisk Institut udgivet af Videnskabsbutikkens forlag under titlen: Forestillede Forskelle - Et sociologisk studie af frellesskaber mellem unge med forskellige etniske baggrunde (2006).

3. Dette kan ses som et eksempel på, at der i visse tilfælde kan opstå en række transetniske og transkulturelle møder blandt de unge i storbyens kulturelle og sociale rum. Den danske forskning har dog hidtil kun behandlet dette tema i meget begrænset omfang.

4. Den stærke følelsesmæssige karakter, som dette fællesskab har for de unge, kan belyses med Berger og Luckmanns teorier om virkelighedsforståelser, idet forældrenes virkelighed, der internaliseres i den primære socialisation, som regel består på trods af stærke udfordringer senere i livet.

5. Flemming Røgilds beskriver i bogen Stemmer i et grænseland - en bro mellem unge indvandrere og danskere? hvorledes unge "indvandrere" og "danskere" bygger bro mellem sig ved at samordne en blanding af forskellige etniske, kulturelle og nationale perspektiver. Således udforsker og overskrider de unge hidtidige kulturelle grænser, hvormed de kan udvikle hvad Røgilds, med reference til Deleuxe \& Guattari, betegner nye intermezzokulturer (Røgilds 1995:255f).

6. Ifølge Zygmunt Bauman vil personer, der tilskrives en bestemt etnisk minoritetsgruppe, tage denne kategori på sig med stolthed, som det eksempelvis er tilfældet med tankegangen bag udsagnet "Black is beautiful" (Bauman 2001:89).

7. Den danske lingvist Pia Quist har beskæftiget med denne sprogbrug, som hun kalder multietnolekt, og som beskriver den sproglige variant, der tales af unge med forskellige etniske baggrunde og modersmål. De sproglige kendetegn ved multietnolekten er en systematisk anderledes bøjning, ordstilling og udtale af danske ord (Quist 2000a:151ff). Brugen af begrebet multietnolekt og diskursen der knytter sig her til, er blevet kritiseret af Mette Vedsgård Christensen. Ifølge hende formår begrebet multietnolekt ikke at omfatte de betydelige forskelle og variationer, der er inden for unge med forskellige etniske baggrundes sprogbrug. I stedet foreslår Christensen begrebet araber-slang, som udtryk for det talesprog nogle unge fra det vestlige Århus taler (Christensen 2006:18).

8. I Erving Goffmans teori om stigmatisering benytter han et lignende eksempel omkring "niggers" som et fællesskab, der er meget svært for andre, for eksempel "hvide", at få adgang til. Kun ved virkelig tætte venskaber er det muligt at blive en del af fællesskabet og bruge betegnelsen, der ellers ses som en fornærmelse (Goffman 1965:29).

9. Norbert Elias gør i studiet af social eksklusion The Established and the Outsiders endvidere opmærksom på, hvordan negativ typificering af en gruppe kan føre til, at den begynder at leve op til den negative karakteristik: "Give a group a bad name and it is likely to live up to it" (Elias \& Scotson 1994:xxvii).

\section{Litteratur}

Anderson, Benedict 1991: Imagined Communities - Reflections on the Origin and Spread of Nationalism. London: Verso.

Azar, Michael 2001: "Den äkta svenskheten och begärets dunkla objekt" i Sernhede, Ove \& Thomas Johansson (red.): Identitetens omvandlingar. Göteborg: Daidalos.

Bauman, Zygmunt 1998: Life in Fragments - Essays in Postmodern Morality. Oxford: Blackwell Publishers Ltd. 
Bauman, Zygmunt 2001: Community. Seeking Safety in an Insecure World. Cambridge: Polity Press.

Berger, Peter L. \& Luckmann, Thomas 1979: The Social Construction of Reality. A Treatise in the Sociology of Knowledge. Middlesex: Penguin Books.

Bourdieu, Pierre 2003: Af praktiske grunde. København: Hans Reitzels Forlag.

Christensen, Mette Vedsgård 2006: “Er vi så perskerdanske? Etnicitet og sprogvariation i Århus V" i Social Politik, nr. 3: 18-23.

Danmarks Statistik 2006: http://www.statistikbanken.dk

Elias, Norbert \& Scotson, John. 1994: The Established and the Outsiders. London: Sage. s. xv-lii.

Goffman, Erving 1975: Stigma. Notes in the Management of Spoiled Identity. København: Gyldendal.

Jensen, Iben 2001: Interkulturel kommunikation i komplekse samfund. København: Roskilde Universitetsforlag.

Mead, George Herbert 1934: Mind, Self and Society. Chicago: University of Chicago Press.

Mørck, Yvonne 1998: Bindestregsdanskere. Fortællinger om køn, generationer og etnicitet. København: Forlaget Sociologi.

Necef, Mehmet Ü. 1992: Etnisk kitsch - og andre (post)moderne fortællinger om „De Andre“. Magisterkonferens. Institut for Kultursociologi. Københavns Universitet.

Necef, Mehmet Ümit 1997 : Elsk mig, bind mig, integrer mig. Grus 18 (52), s. 60-80.

Quist, Pia 2000a: "Ny københavnsk "multietnolekt". Om sprogbrug blandt unge i sprogligt og kulturelt heterogene miljøer".I Danske Talesprog. Bind 1, s. 143-212. Institut for Dansk Dialektforskning. København: C.A. Reitzels Forlag.

Røgilds, Flemming 1995: Stemmer i et grænseland - En bro mellem unge indvandrere og danskere? København: Forlaget politisk revy.

Røgilds, Flemming 2002: Et nyt dansk råstof? Forskning i etniske minoritetsunge fra 19802001. AMID Working Paper Series 24/2002.

Røgilds, Flemming 2002: "Den nye racisme: Aktører. Forhistorie. Modstrategier" i Dansk Sociologi, nr. 3/13: 101-110.

Schneider, David J. 2004: The psychology of stereotyping. New York : Guilford Press.

Simmel, Georg 1950: "The Stranger". I Wolff, Kurt H. (red.): The Sociology of Georg Simmel. New York: The Free Press. 